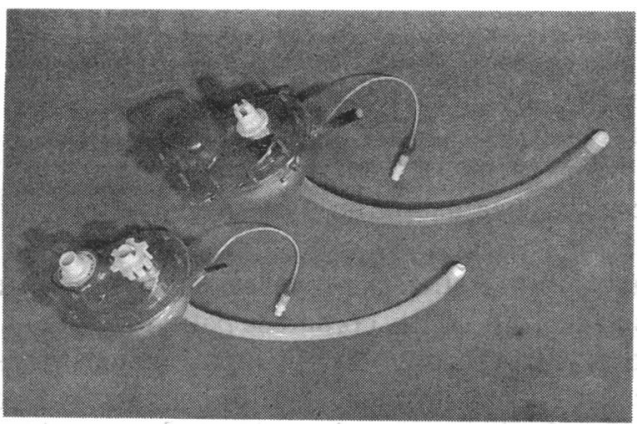

Oesophageal obdurators

Oesophageal obdurators are popular in the USA. The obdurator is a long cuffed tube attached to a facemask. The tube is passed blindly into the oesophagus and the cuff is then inflated to isolate the oesophagus and stomach from the airway. In the original version the oesophageal obdurator tube is blocked distally and a series of holes at laryngeal level permit air blown down the tube to pass from the tube into the larynx. In a later version the oesophageal tube is not terminally sealed and this allows for aspiration or pressure relief of gastric contents. A second orifice in the mask is used for ventilation. Hazards in the use of these tubes include trauma to the oesophagus and stomach, the risk of inducing vomiting and gastric rupture, and, paradoxically, the rare occurence of unrecognised tracheal intubation.

Dr Robert Simons, FFARACS, FFARCs, is consultant anaesthetist and Dr Hilary Howells, FFARCS, director of department of anaesthesia, Royal Free Hospital, London NW3 2QG.

\title{
Epidemiology
}

\section{An outbreak of gastrointestinal illness associated with consumption of raw depurated oysters}

\author{
D HELLER， O N GILL， E RAYNHAM， T KIRKLAND， P M ZADICK, \\ R STANWELL-SMITH
}

A lunch time reception was held in March 1985 for French visitors as part of a twin town celebration at which a seafood menu which included raw oysters was served. The next day, while the French visitors travelled home, some of the English guests became ill with diarrhoea, abdominal pain, and vomiting, and an investigation was begun.

\section{Methods}

A cohort study was conducted using a short postal questionnaire which asked about the foods eaten, occurrence of illness, and the nature and onset time of symptoms. After consultation with the French Department of Health a translated questionnaire was delivered to each of the French visitors via their local mayor.

Faecal samples collected from four guests several days after onset of illness were examined bacteriologically. The source, trans-

Newham Health Authority, London EC15 1HR

D HELLER, MB, registrar in community medicine

North East Thames Regional Health Authority, London W2

O N GILL, MFCM, consultant epidemiologist

Maldon District Council, Essex

E RAYNHAM, environmental health officer

T KIRKLAND, MB, DPH, medical officer for environmental health

Chelmsford Public Health Laboratory, Chelmsford

P M ZADICK, BM, acting director

Communicable Disease Surveillance Centre, London NW9 5EQ

R STANWELL-SMITH, MB, senior registrar portation, storage, and preparation of each of the foods were documented, and the relevant premises visited and examined. Bacterial monitoring records from the oyster fishery were reviewed.

\section{Results}

Replies were received from all of the 29 English guests and from 22 of the 25 French guests. Of the 51 responders, $13(25 \%)$ became ill within 48 hours of the meal (median incubation period was 36 hours) and a further three suffered gastrointestinal upset during the week after the reception. The main clinical features were diarrhoea, nausea, and loss of appetite, and half those affected also complained of vomiting.

For the calculation of food specific attack rates a case definition of diarrhoea, abdominal pain, or vomiting beginning within 48 hours of the reception was used; those whose illness did not meet the case definition were excluded from the analysis. Very few people drank non-alcoholic beverages, and of the six available food items, only the oysters were significantly associated with illness (table); all of the 13

Food specific attack rates

\begin{tabular}{|c|c|c|c|c|c|}
\hline \multirow[b]{2}{*}{ Food } & \multicolumn{2}{|c|}{ Number } & \multicolumn{2}{|l|}{ Number } & \multirow{2}{*}{$\begin{array}{c}\text { Probability } \\
\text { (Fisher's exact test } \\
\text { two tailed) }\end{array}$} \\
\hline & Who ate & Ill (\%) & Who did not eat ${ }^{\star}$ & III (\%) & \\
\hline $\begin{array}{l}\text { Fish balls } \\
\text { Tomato dressing } \\
\text { Mussels } \\
\text { Cockles } \\
\text { Oysters } \\
\text { Prawns }\end{array}$ & $\begin{array}{l}41 \\
26 \\
42 \\
43 \\
36 \\
43\end{array}$ & $\begin{array}{r}13(32) \\
9(35) \\
12(29) \\
13(30) \\
13(36) \\
12(28)\end{array}$ & $\begin{array}{r}5 \\
19 \\
5 \\
3 \\
10 \\
1\end{array}$ & $\begin{array}{l}0 \\
4(21) \\
1(20) \\
0 \\
0 \\
0\end{array}$ & $\begin{array}{c}\text { NS } \\
\text { NS } \\
\text { NS } \\
\text { NS } \\
\mathrm{p}<0 \cdot 01 \\
\text { NS }\end{array}$ \\
\hline
\end{tabular}

"Excluding people who did not reply to particular food items. NS= not significant, all $>0 \cdot 2$. 
ill people ate the oysters. For some of the food items, however, nearly everyone ate a portion, and comparisons of attack rates with people who did not eat a food item could be only tentative. The preparation details of the other foods suggested that they had been adequately cooked, and the oysters were eaten raw.

There were isolated reports of gastrointestinal illness associated with oysters in the town at the same time among people who had not attended the reception. An unexplained finding was the markedly different attack rates between the English (11/20, 55\%) and the French $(2 / 16,13 \%)$. Pathogenic bacteria were not cultured from any of the four stool specimens.

\section{Oysters}

Coliform counts from the oyster fishery on the River Teign in Devon, three days before despatch of the suspect oysters, showed an initial figure before treatment of $35000 / 100 \mathrm{ml}$ of body tissue, falling to $330 / 100 \mathrm{ml}$ after 72 hours depuration. Around 500 Pacific oysters, already depurated for 72 hours, were brought from the fishery and transported to a fish market from where the retailer collected them the following day. They were then stored in a depuration plant and treated with seawater circulated continuously through ultraviolet light for 15 days until taken to the reception. Water in the tank where this prolonged depuration took place was circulated through the plant for at least 72 hours before introduction of the oysters.

\section{Discussion}

The pattern of illness in this outbreak was similar to that of acute non-bacterial gastroenteritis, also described as "Norwalk like"; the illness was of short duration, over half those affected vomited, the median incubation period was 36 hours, and recognised bacterial pathogens were not isolated from convalescent stool specimens.
Unfortunately no acute stool specimens were available for electron microscopy.

The food specific attack rates suggested that oysters were the vehicle of infection. The difference in attack rates between the English guests and their French visitors was unexplained. Possibly the French guests had previously been exposed to the particular strain of virus.

Large outbreaks of viral gastroenteritis have been reported associated with the consumption of raw oysters, ${ }^{2-4}$ and in some of these outbreaks the oysters had been cleansed by depuration for at least 72 hours. $^{45}$ Although harvested originally from grossly polluted waters, the oysters implicated in the present outbreak underwent prolonged depuration. There was, however, some doubt about the second 15 day depuration period in that this plant was occasionally topped up with untreated seawater while in operation, and we could not be certain that this had not occurred. Nevertheless, the outbreak suggests the possibility that even prolonged depuration may not remove certain viruses from oysters. In the belief that relaying in a natural environment may be more efficient than depuration at removing pathogenic viruses, it has been suggested that oysters grown in heavily polluted waters should be relayed in approved clean waters for several days before cleansing in a tank depuration system. ${ }^{6}$

\section{References}

1 Kaplan JE, Feldman R, Campbell DS, Lookabaugh C, Gary GW. The frequency of a Norwalk-like pattern of illness in outbreaks of acute gastroenteritis. Am $\mathcal{J}$ Public Health 1982;72:1329-32.

2 Murphy AM, Grohmann GS, Christopher PJ, Lopez WA, Davey GR, Millsom RH. An Australiawide outbreak of gastroenteritis from oysters caused by Norwalk virus. Med $\mathcal{F}$ Aust 1979; ii: 329-33.

3 Linco SJ, Grohmann GS. The Darwin outbreak of oyster-associated viral gastroenteritis. Med $\mathcal{J}$ Aust 1980;i:211-3.

4 Gill ON, Cubitt WD, McSwiggan DA, Watney BM, Bartlett CLR. Epidemic of gastroenteritis caused by oysters contaminated with small round structured viruses. Br Med f 1983;287:1532-4.

5 Grohmann GS, Murphy AM, Christopher PJ, Auty E, Greenberg HB. Norwalk virus gastroenteritis in volunteers consuming depurated oysters. Aust f Exp Biol Med Sci 1981;59:219-28. West PA, Wood PC, Jacob M. Control of food poisoning risks associated with shellfish. Fournal of the Royal Society of Health 1985 ; i: $15-21$.
PHLS Communicable Disease Surveillance Centre, London NW9 5EQ

GIUSEPPE MARASCA, MD, MSC, epidemiologist on secondment from Istituto Superiore di Sanita Laboratorio di Epidemiologia e Biostatistica, 00161 Rome, Italy

MARIAN MCEVOY, MB, MFCM, consultant epidemiologist those with both Kaposi's sarcoma and $P$ carinii pneumonia. There were significant differences between durations of survival of patients with Kaposi's sarcoma and those with all other diseases, which indicated impaired cellular immunity apart from opportunistic infections.

This analysis shows that those with Kaposi's sarcoma alone have the most favourable prognosis.

\section{Introduction}

During 1981 reports of patients with the acquired immune deficiency syndrome (AIDS) in the United States were published, and in December of that year the first case of AIDS diagnosed in a homosexual man in Britain was documented. ${ }^{2}$ In 1982 a surveillance scheme was set up by the Public Health Laboratory Service Communicable Disease Surveillance Centre (CDSC) in collaboration with the Communicable Disease (Scotland) Unit. Up to 1 June 1985,178 cases were reported. We reviewed these cases to assess the duration of survival. 